\title{
First report of Dryopteris namegatae and reexamination of D. hangchowensis (Dryopteridaceae) from Korea
}

\author{
Chang Shook Lee ${ }^{1, *}$, Kanghyup Lee ${ }^{2}$ and Youngsim Hwang ${ }^{3}$ \\ ${ }^{1}$ Department of Science Education, Ewha Womans University, Seoul 120-750, Korea \\ ${ }^{2}$ Pyunggang Botanical Garden, Pocheon, Gyeonggi-do 487-892, Korea \\ ${ }^{3}$ Geobook, Seoul 110-873, Korea
}

*Correspondent:ferncslee@hanmail.net/leecs@ewha.ac.kr

\begin{abstract}
One newly recorded species, Dryopteris namegatae, sect. Hirtipedes, was collected in forests in Jeju-do. Dryopteris namegatae (vernacular name: 'Tam-ra-top-ji-ne-go-sa-ri') was distinguished from other Korean congeners of sect. Hirtipedes of the genus Dryopteris by having stiff black scales on stipe and rachis, less narrowed base of lamina, and adaxial surface of pinna immersed along veins. Dryopteris hangchowensis ('Gak-si-top-ji-ne-go-sa-ri', new local name), recorded without any comments and description, was reexamined with similar taxa and was distinguished by smaller plants, brilliant leaves, many prominent fimbriate blackish scales on stipe and rachis, long-pointed apex of lamina and pinna, halfway-lobed pinna, and narrowest pinna. Descriptions and illustrations of the two species and their photographs in the habitat are provided along with a key to the species of sect. Hirtipedes of Dryopteris in Korea.
\end{abstract}

Keywords: D. hangchowensis, Dryopteris namegatae, first report, reexamination, Sect. Hirtipedes of Dryopteris

\section{INTRODUCTION}

The genus Dryopteris Adans. (Dryopteridaceae), known as wood fern, contains 225 to 300 species that are widely distributed in the temperate Northern Hemisphere, has the highest species diversity in eastern Asia, and is one of the largest genera in Dryopteridaceae (Fraser-Jenkins, 1986; Sessa et al., 2012; Zhang et al., 2012). Fraser-Jenkins (1986) provided a worldwide classification and divided Dryopteris into four subgenera [subgen. Pycnopteris (T. Moore) Ching, subgen. Dryopteris, subgen. Erythrovariae (H. Itô) Fraser-Jenk., and subgen. Nephrocystis (H. Itô) Fraser-Jenk.]. Among these, the subgenus Dryopteris has characters of fronds not imparipinnate, pinnae gradually reduced to a pinnatifid apex, bullate scales on the underside of the pinna-costa absent, pinna segments usually symmetrical and not sloping or auricles at the acroscopic base (Fraser-Jenkins, 1986).

According to Fraser-Jenkins (1986), subgenus Dryopteris is divided into 11 sections [sect. Hirtipedes FraserJenkins, sect. Fibrillosae Ching, sect. Pandae FraserJenkins, sect. Dryopteris, sect. Remotae Fraser-Jenkins, sect. Pallidae Fraser-Jenkins, sect. Splendentes Fraser-
Jenkins, sect. Cinnamoneae Fraser-Jenkins, sect. Marginatae Fraser-Jenkins, sect. Aemulae Fraser-Jenkins, and sect. Lophodium (Newman) C. Chr. ex H. Itô]. This classification of Dryopteris was adapted by Hoshizaki and Wilson (1999) as studying about fifty species of Dryopteris, belonging to three subgenera and ten sections, are known to be in cultivation of the United States. Lu (1993) classified as 3 subgenera 12 sections as studying about 88 taxa of Dryopteris in Yunnan, which was also proposed two new sections in subgenus Dryopteris. The base chromosome number of Dryopteris is $n=41$ (Liu et al., 2007), but polyploidy is common, and Dryopteris is considered extremely prone to hybridization (Manton, 1950). The potential roles of reticulate evolution and polyploidy in the genus have long been recognized (Stein et al., 2010).

The taxonomic status of the sections in subgenus Dryopteris has not been clarified. And phylogenetic studies for clarification of the taxonomic status of the sections in subgenus Dryopteris had been carried out recently based on molecular data with morphology (Geiger and Ranker, 2005; Li and Lu, 2006a; 2006b; Liu et al., 2007; Sessa et al., 2012; Zhang et al., 2012).

The sect. Hirtipedes Fraser-Jenkins is as follows: leaf blades once pinnate, pinnae only shallowly lobed or 
lobed to only half their depth or less except at the very base of the lowest few pinnae, and stipe scales mostly linear-lanceolate (Fraser-Jenkins, 1986).

Korean ferns belonging to sect. Hirtipedes has been reported as Dryopteris atrata (Wall. ex Kunze) Ching, $D$. cycadina (Franch. \& Sav.) C. Chr., D. dickinsii (Franch. \& Sav.) C. Chr., and D. commixta Tagawa (Lee, 2006; Kim and Sun, 2007; Park et al., 2008). Further, Dryopteris lunanensis $(\mathrm{H}$. Christ) C. Chr. was reported as the local name 'Nam-do-top-ji-ne-go-sa-ri' for the first time at Mt. Samgaksan in Gwangju by Kim et al. (2004). It contains 15 pairs-lateral pinnae, pinnae deeply lobed, shallowly to halfway to costae, or pinnatisect near basal portion of pinnae, and sori adhered to middle part more of frond. The local name 'Nam-do-top-ji-ne-go-sa-ri' was used different scientific name as Dryopteris hangchowensis Ching, distributed in Jeonnam without any comments in the Genera of Vascular Plants of Korea by Kim and Sun (2007).

Regarding the range limit of species in sect. Hirtipedes of Dryopteris, there is some diversity of opinions. The local name 'Top-ji-ne-go-sa-ri' was used to Dryopteris atrata (Wall. ex Kunze) Ching (Park, 1975; Lee, 1980; Lee, 2006), whereas it has been misidentified as Dryopteris cycadina (Franch. \& Sav.) C. Chr. (Kim and Sun, 2007; Park et al., 2008), as the description, shining black scales in Park et al. (2008). Dryopteris cycadina, which is distributed in Japan, China, and Taiwan, is distinguished from $D$. atrata by brown to reddish brown scales, although it has been used in mixed state as a synonym of $D$. atrata (Shieh et al., 1994; Iwatsuki, 1995). Nowadays, these taxa are treated separately (Flora of China Editorial Committee, 1988-2013; Li and Lu, 2006a; 2006b; Dong, 2010). We treated 'Top-ji-ne-go-sa-ri' observed at Jejudo in Korea as not D. cycadina but Dryopteris atrata based on shining black scales.

In the present study, Dryopteris namegatae (Sa. Kurata) $\mathrm{Sa}$. Kurata is reported as newly recorded taxa from Korea, and it was collected at a forest in Dororeum, Hallimeup, Jeju-si and Gyorae-gotjawal, Seogwipo-si, Jeju-do. And also, D. hangchowensis Ching, recorded as local name 'Nam-do-top-ji-ne-go-sa-ri' and only scientific name by Kim and Sun (2007) without any comments and any description, is reexamined. These taxa were previously known as a rare plant from Japan and China (Iwatsuki, 1995). Dryopteris namegatae is distinguished based on stiff black scales on stipe and rachis, less narrow base of lamina, and patently immersed adaxial vein of pinna (Kurata, 1969; Kurata and Nakaike, 1985; Nakaike, 1992; Iwatsuki, 1992). The local name was given as 'Tam-ra-topji-ne-go-sa-ri' based on detection site. D. hangchowensis is distinguished from similar taxa based on smaller plant height, brilliant leaves, many prominent fimbriate blackish scales on stipe and rachis, long-pointed apex of lamina and pinna, halfway-lobed pinna, and narrowest pinna (Kurata and Nakaike, 1985; Iwatsuki, 1992; Nakaike, 1992). The local name was given as 'Gak-si-topji-ne-go-sa-ri' based on the pretty frond shape.

We compared and analyzed morphological characters between $D$. namegatae and $D$. hangchowensis, and similar taxa of sect. Hirtipedes, in order to understand the taxonomic relationship among those taxa. The morphological characters and illustrations of D. namegatae and $D$. hangchowensis, along with the photographs in the habitat, are newly reported with a taxonomic key to the species of sect. Hirtipedes of Dryopteris in Korea.

\section{Materials ANd Methods}

One unrecorded and one reexamined species (Dryopteris namegatae and D. hangchowensis) (Figs. 1, 2) were collected first in Korea, and the voucher specimens were deposited in the National Institute of Biological Resources (NIBR) and Ewha Womans University Herbarium (EWH). To reveal the taxonomic positions of Dryopteris namegatae and $D$. hangchowensis, 17 morphological characters (Table 1) based on observed morphological data and the reported data of the flora and illustrated books (Kurata and Nakaike, 1979; 1985; Nakaike, 1992; Iwatsuki, 1992; 1995) were compared for eight taxa with two taxa distributed in Japan and China as having more similar characters to them of sect. Hirtipedes of Dryopteris (Table 1).

\section{Taxonomic Treatment and Description}

Dryopteris namegatae (Sa. Kurata) Sa. Kurata in J. Geobot. (Kanazawa) 17: 89(1969)

Basion. Dryopteris dickinsii var. namegatae Sa. Kurata in J. Geobot. (Kanazawa) 4: 115-116 (1958)

Korean name: Tam-na-top-ji-ne-go-sa-ri (탐라톱지 네고 사리)

Winter green herb, height $50-80 \mathrm{~cm}$. Rhizomes short, thick, erect, bearing several fronds in a whorl, scaly; scales lanceolate, entire margin, pale blackish, $8-10 \mathrm{~mm}$ length, 2-3 mm width. Stipes $18-25 \mathrm{~cm}$ length, $2-3 \mathrm{~mm}$ width, commonly scaly throughout; scales lanceolate to linear lanceolate, stiff black, small projection at margin, gradually caudate at apex, blackish, 3-8 mm length, 0.2$1.5 \mathrm{~mm}$ width. Laminae once pinnate, 15-17 lateral pinnae pairs, widest at middles, oblong lanceolate, gradually narrowing towards acuminate apex, lower pinnae a little shortened, papyraceous, $35-50 \mathrm{~cm}$ length, $20-27 \mathrm{~cm}$ 


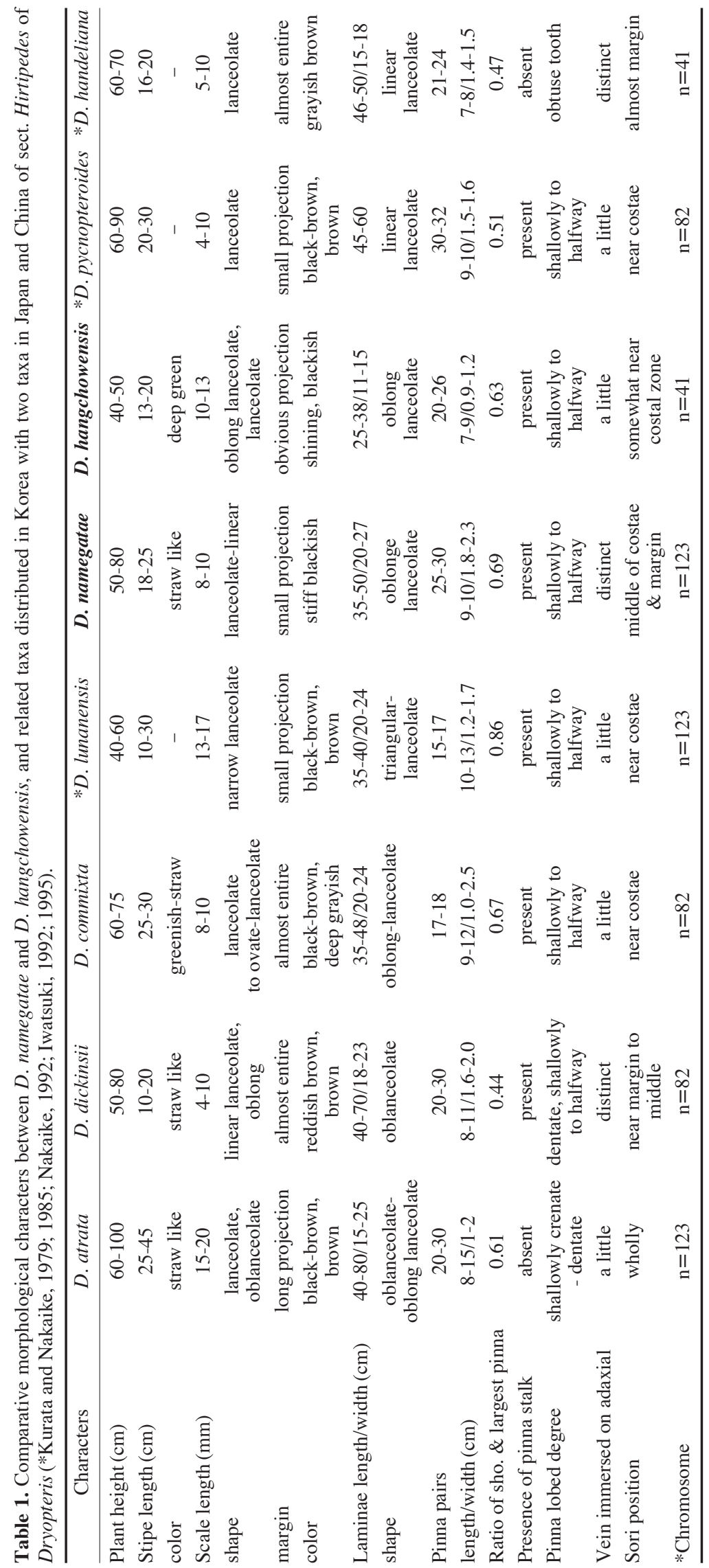



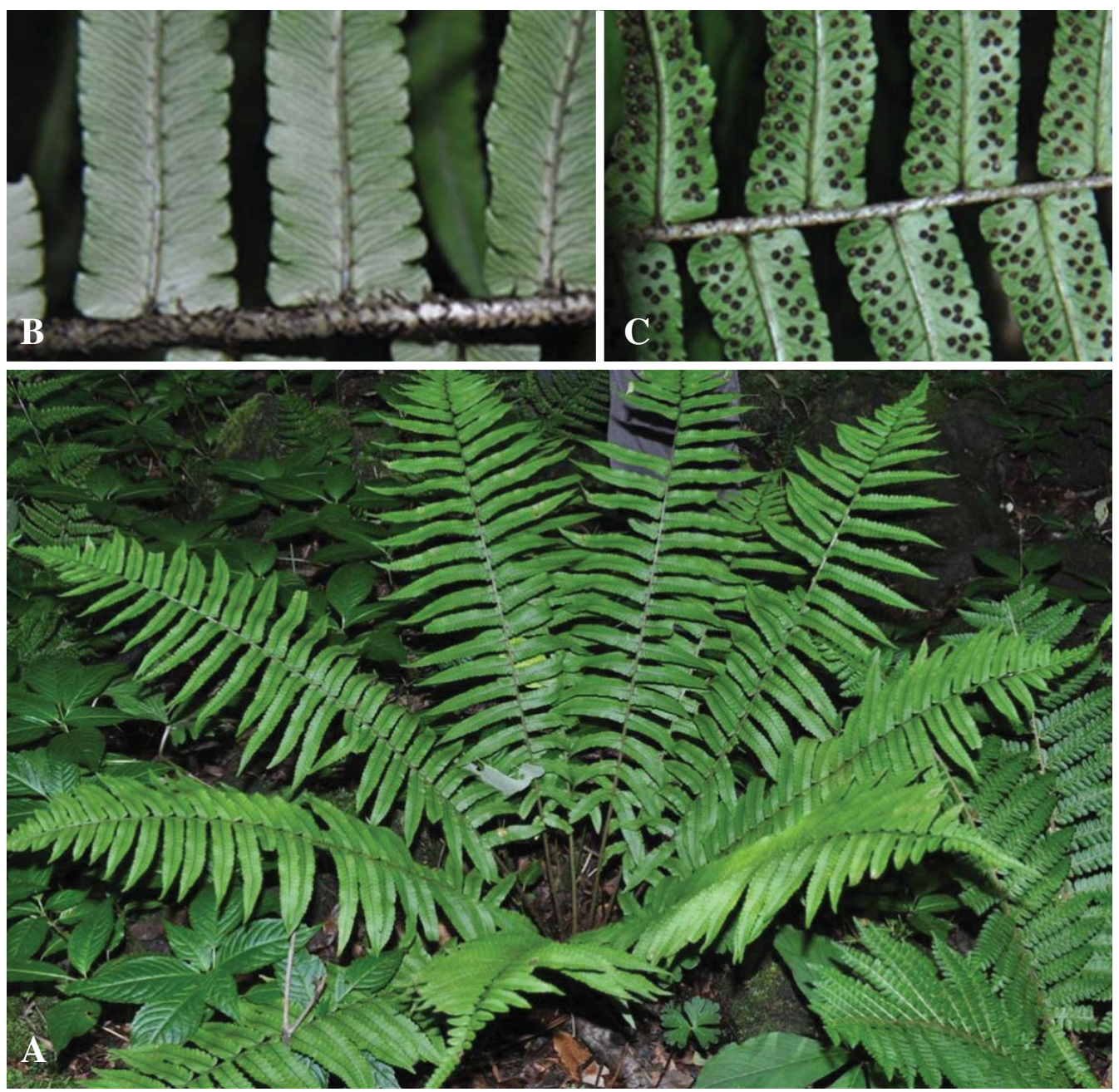

Fig. 1. Photographs of Dryopteris namegatae (Sa. Kurata) Sa. Kurata, taken in Dororeum, Hallimeup, Jeju-si, Jeju-do on 8 Sept. 2012 by Sun-yeul Ko. A. Habit. B. Scale on rachis and immersed vein. C. Abaxial surface with sori and indusium.

width, basal 2-3 pairs of lateral pinnae deflexed a little; rachis straw colored, with smaller scales than stipe; scales with irregular projection at margin, stiff black; lateral pinnae 25-30 pairs, linear, 9-10 $\mathrm{cm}$ length, $18-23 \mathrm{~mm}$ width, broadly cuneate to truncate at base, short-stalked about $1 \mathrm{~mm}$ length, lobed shallowly to halfway; lobes bearing a few teeth, deep green, paler beneath; veinlets simple, distinctly immersed on adaxial surface. Sori dispersed somewhat medial to subcostular zone; indusial roundrenifom, subentire.

Distribution: Korea, Japan and China. In mountain areas.

Specimens examined: Gyorae-gotjawal, Seogwipo-si, Jeju-do, Korea, 8 June 2012, C.S. Lee \& G.H. Lee 1206 001-2; Dororeum, Hallimeup, Jeju-si, Jeju-do, 8 Sept. 2012, C.S. Lee \& G.H. Lee 1209010-5.

The new local name 'Tam-na-top-ji-ne-go-sa-ri' was given based on the locality. It was first found in Korea with $D$. dickinsii, D. fuscipes, D. uniformis, D. erythrosora, Polygonatum inflatum, Arisaema amurense var. serratum, Quercus myrsinaefolia, Camellia japonica, and Hedera rhombea in a forest in Gyorae-gotjawal, Seogwipo-si, Jeju-do.

Dryopteris hangchowensis Ching in Bull. Fan Mem. Inst. Biol., Bot. 8 (6): 414 (1938)

Korean name: Gak-si-top-ji-ne-go-sa-ri (각시톱지네고 사리)

Winter green herb, height $40-50 \mathrm{~cm}$. Rhizomes short, thick, erect, bearing several fronds in a whorl, densely scaly; scales lanceolate, suddenly narrowing near apex, fimbriate margin with irregular small projection at base, shining blackish brown to black, 10-13 mm length, 2-3 $\mathrm{mm}$ width. Stipes $13-20 \mathrm{~cm}$ length, 3-4 mm width, green, 


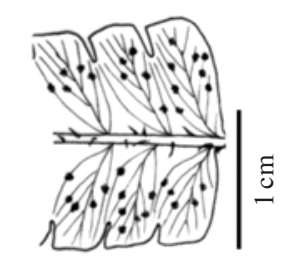

D
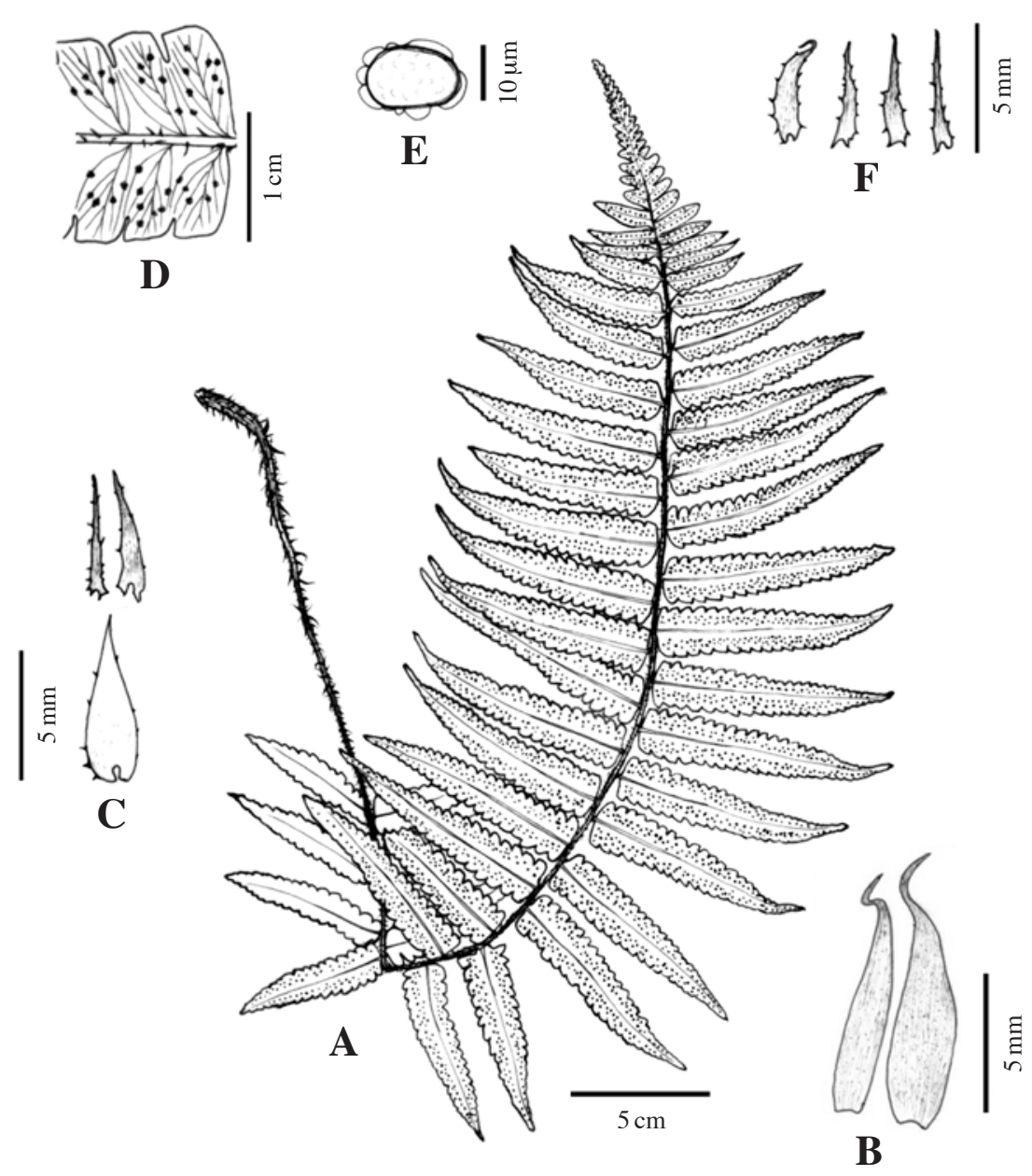

Fig. 2. Illustrations of Dryopteris namegatae (Sa. Kurata) Sa. Kurata. A. Habit. B. Scales on base of stipe. C. Scales on middle of stipe. D. pinna. E. Spore. F. Scales on rachis.

densely scaly throughout; many scales linear lanceolate to linear, with obvious irregular spinule like projections at margin, filamentous caudate at apex, shining blackish brown, 3-10 mm length, 0.2-2.0 mm width. Laminae once pinnate, 20-26 lateral pinnae pairs, widest at middles, oblong lanceolate to lanceolate, gradually narrowing towards acuminate apex, lower pinnae shorter, brilliant, texture herbaceous, $25-38 \mathrm{~cm}$ length, $11-15 \mathrm{~cm}$ width, basal 2-3 pairs of lateral pinnae deflexed; rachis deep green, copiously, and costae beneath sparsely clothed in black, linear-subulate, many fimbriate scales; pinnae linear, 7-9 cm length, 9-12 $\mathrm{mm}$ width, rounded at base, short-stalked about $1 \mathrm{~mm}$ length, lobed halfway to costae, lobes becoming almost separate at the base of the lowest pinnae; lobes with 2-3 crenate teeth and one sharp distal tooth, deep green, paler beneath; veinlets simple. Sori dispersed somewhat near costal zone; indusial roundrenifom, subentire, persistent.

Distribution: Korea, Japan, south-east China, Taiwan. In the mountain area.
Specimens examined: Mudeungsan, Gwangju-jikhalsi, Korea, 24 Oct. 2012, C.S. Lee \& G.H. Lee 1210100-6.

The new local name 'Gak-si-top-ji-ne-go-sa-ri' was given based on the pretty fronds shape. It was found in Korea with $D$. fuscipes, $D$. uniformis, $D$, bissetiana, $D$. erythrosora, Cyrtomium fortunei, Cryptomeria japonica, and Trachelospermum asiaticum, in a forest in Mudeungsan, Gwangju-jikhalsi.

\section{Discussion}

The new reported and reexamined taxa in Korea, Dryopteris namegatae (Sa. Kurata) Sa. Kurata and D. hangchowensis Ching were leaf blades once pinnate, pinnae only shallowly lobed or lobed to only half their depth or less except at the very base of the lowest few pinnae, and stipe scales mostly linear-lanceolate. These characters correspond with the characters of sect. Hirtipedes FraserJenkins, as devised by Fraser-Jenkins (1986). In a phylo- 

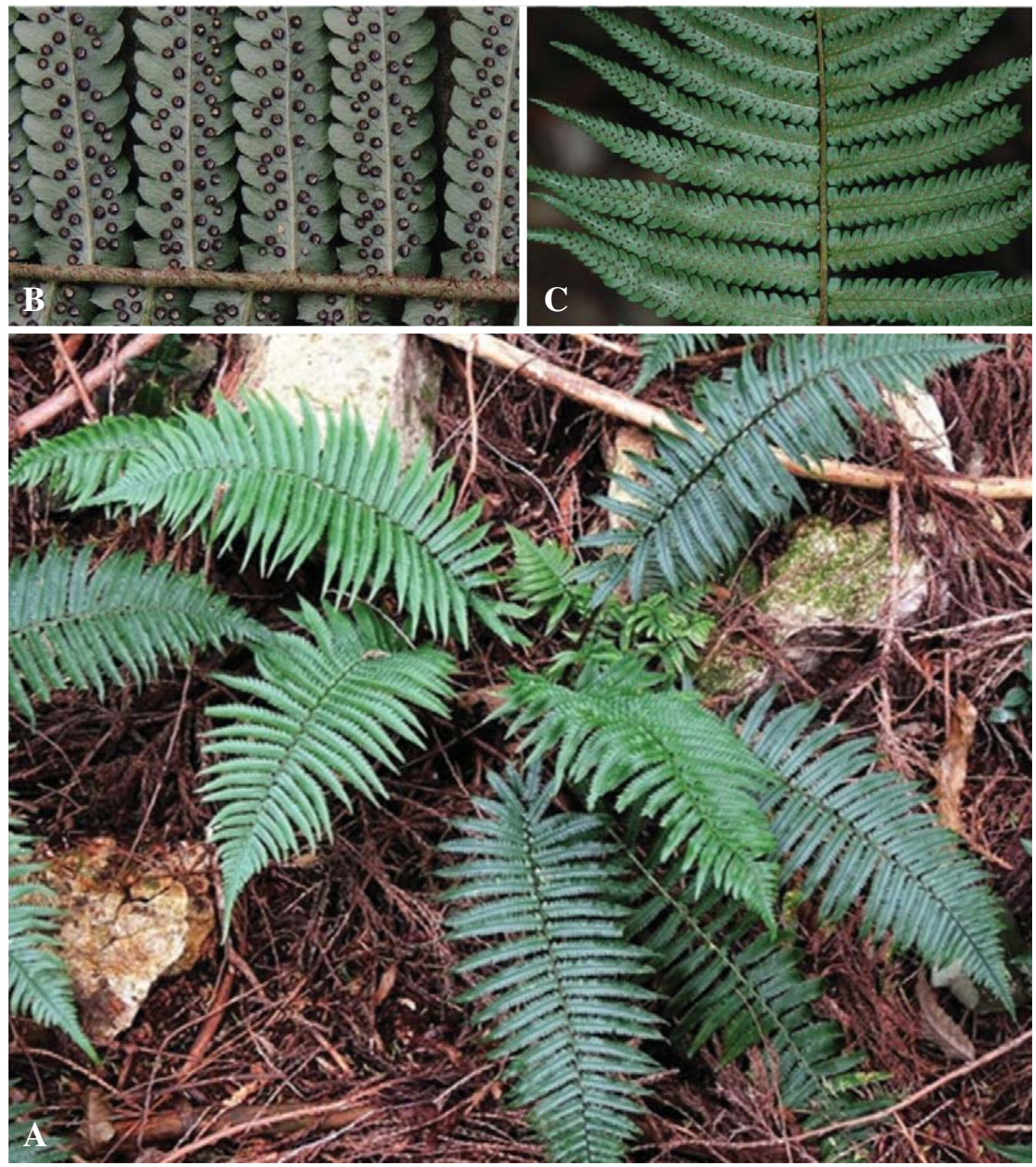

Fig. 3. Photographs of Dryopteris hangchowensis Ching, taken in Mudeungsan, Gwangju-jikhalsi on 24 Oct. 2012 by Ganghyup Lee. A. Habit. B. Abaxial surface with sori and indusium. C. Lateral pinna of upper lamina.

genetic studies on the subgenus Dryopteris based on molecular data (Zhang et al., 2012), it was suggested that 14 taxa with $D$. hangchowensis of sect. Hirtipedes form a monophyletic clade. These results suggest that D. namegatae and $D$. hangchowensis could be treated within sect. Hirtipedes.

Eight taxa of sect. Hirtipedes in Dryopteris, including two new recorded taxa, were compared in Table 1 in order to determine the taxonomic status of the two newly recorded and reexamined taxa.

Dryopteirs namegatae (Sa. Kurata) Sa. Kurata has intermediate characters as the hybrid between $D$. atrata and D. dickinsii without no hybrid name (Iwatsuki, 1995). It is similar with $D$. atrata as blackish and stiff scales on stipe and rachis, widest laminae at middle, a little shortened lower pinnae, and sori in medial to subcostular. Further, it is similar with $D$. dickinsii as the entire margin of scales on stipes, distinctly immersed on adaxial surface, and present pinna stalk. It has the widest lamina and pinna among all taxa of sect. Hirtipedes, and scales are shaped as the entire margin on stipes and small projections on rachis (Table 1).

Dryopteris hangchowensis is similar to D. atrata based on lamina oblong-lanceolate, fimbriate scales, lateral pinnae more than 17 pairs, ratio of basal pinna and largest pinna about $3 / 5$, and the former differs with the 


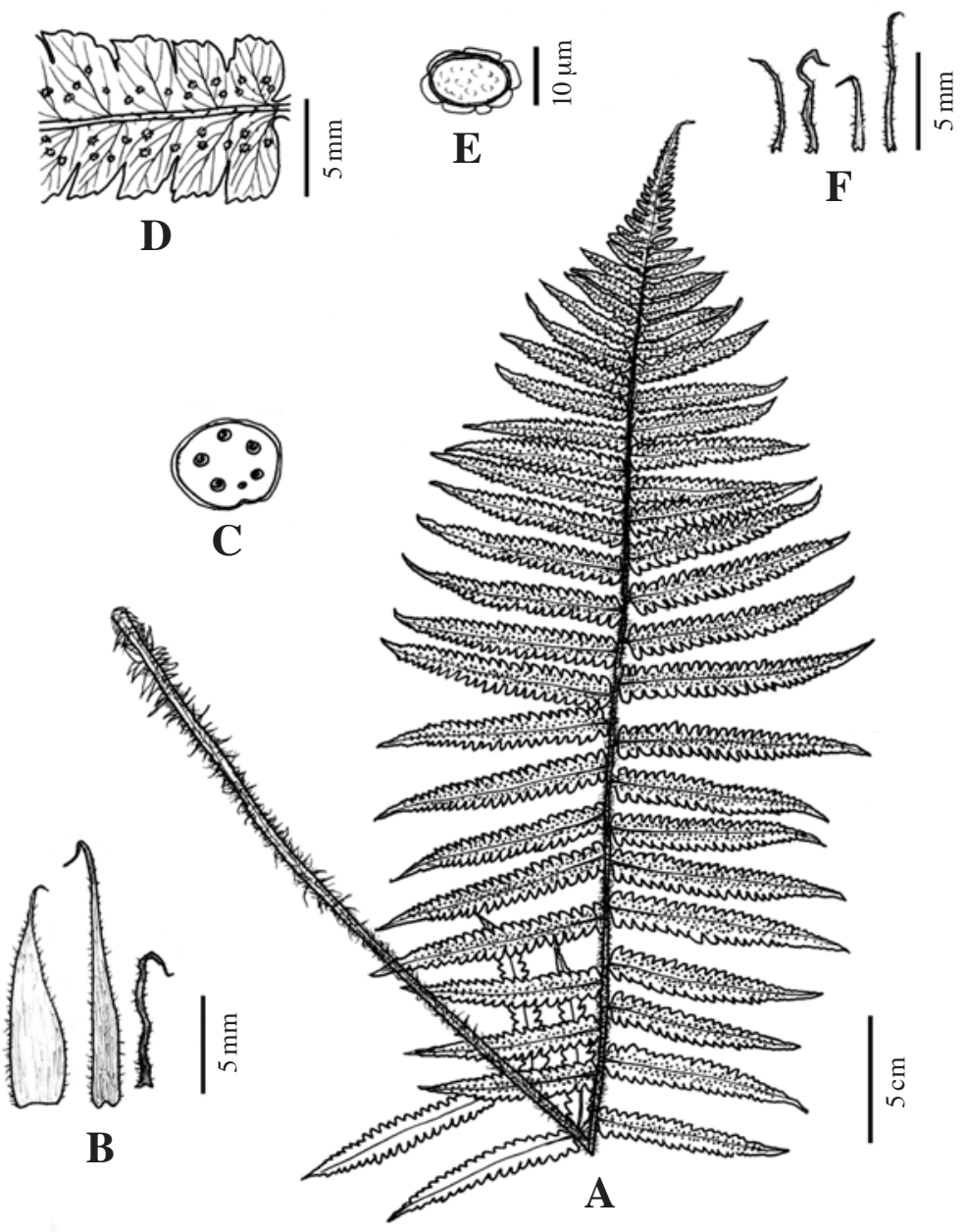

Fig. 4. Illustrations of Dryopteris hangchowensis Ching. A. Habit. B. Scales on stipe. C. Cross section of stipe. D. Pinna. E. Spore. F. Scales on rachis.

latter based on smaller plant height, deep green stipe and rachis, shallowly to halfway lobed pinna, and present pinna stalk (Table 1).

It need to reveal to mistake or misidentification of using as Dryopteris hangchowensis Ching, local name 'Nam-do-top-ji-ne-go-sa-ri', without any comments in the Genera of Vascular Plants of Korea by Kim and Sun (2007), although they had reported as an unrecorded species, D. lunanensis (local name; 'Nam-do-top-ji-ne-gosa-ri') at Mt. Samgaksan in Gwangju by Kim et al. (2004). We asked the author for the voucher specimen of ' $D$. lunanensis' used by Kim et al. (2004), but we could not obtain them due to storage problems. We had a chance to confirm it with Mr. Kim Jong Whan, collecting this voucher specimen on May, 2003 for paper of Kim et al. (2004). However, we could not identify D. lunanensis at any sites containing Mt. Samgaksan in Gwangju after first finding. Although we collected at Mt. Samgaksan in Gwangju, the fern predicted as a hybrid between $D$. commixta and D. uniformis by having similar characters to the former as scales margin on rachis almost entire, linear pinnae, and the latter as deeply lobed, sori distributed in middle part more of frond. We should be suggested that 'Nam-do-top-ji-ne-go-sa-ri' is a hybrid between $D$. commixta and $D$. uniformis, not $D$. lunanensis nor $D$. hangchowensis, and it presume to the same thing as a taxon collected by us based on the photo (Fig. 1, C, D) and description (pages 4, 5) by Kim et al. (2004) although it need more study.

Dryopteris hangchowensis Ching has lateral pinnae more than 17 pairs, ratio of basal pinna and largest pinna smaller than 4/5, lamina oblong-lanceolate, and narrower pinna depth as the clearly different characters with D. lunanensis (H. Christ) C. Chr. (Table 1). These results suggest that this species observed at Mudeungsan is $D$. hangchowensis, but not $D$. lunanensis.

Dryopteris commixta Tagawa, known as an endemic species in Japan, was reported with a photo or illustration in Gwangju, Geoje-do and Jeju-do, Korea by Lee (2006), and Park et al. (2008). This species is similar to 
D. lunanensis, D. hangchowensis, and D. pycnopteroides based on the pinna stalk present, shallowly to halfway and slightly immersed vein. Moreover, Dryopteris commixta has almost an entire margin of scales, scales on stipes less shining, blackish brown to deep grayish, and poorly developed indusium (Table 1).

Dryopteris pycnopteroides (H. Christ) C. Chr. and D. handeliana $\mathrm{C}$. Chr. are distributed in Japan and China. The former has the characters of more deeply dissected pinnae, sinus subtriangular pinnae, reduced lower pinnae length, and small swelling pinna costae. The latter is similar to $D$. dickinsii based on the shortened lower pinnae, sori position near margin, and distinctly immersed vein, but it is different based on the suddenly becoming shorter upper lateral pinnae and grayish brown scales on base of stipe.

Dryopteris namegatae and D. hangchowensis can be distinguished from the similar taxa of sect. Hirtipedes in the genus Dryopteris in Korea as follows:

1. Sori several rows or dispersed near costal to medial site, veinlets a little immersed.

2. Lateral pinnae 15-17 pairs, ratio of basal pinna and

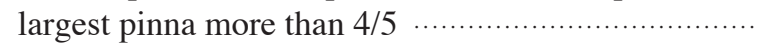

D. lunanensis or hybrid 남도톱지네고사리

2. Lateral pinnae more than 17 pairs, ratio of basal pinna and largest pinna less than $4 / 5$.

3. Pinna shallowly crenate to dentate, stalk sessile ….

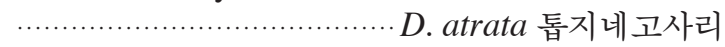

3. Pinna shallowly to halfway, stalk present.

4. Scales margin on rachis almost entire, pinnae less than 20 pairs, widest at lower part of lamina ….... ..................... D. commixta 애기톱지네고사리

4. Scales margin on rachis fimbriate, pinnae more than 20 pairs, widest at middle part of lamina.

5. Stipe and rachis color straw like, scales on stipe almost entire, pinna width $1.8-2.3 \mathrm{~cm} \ldots \ldots \ldots \ldots \ldots$

D. namegatae 탐라톱지네 고사리

5. Stipe and rachis color green, scales on stipe conspicuously fimbriate, narrowest pinna width less than $1.2 \mathrm{~cm}$

D. hangchowensis 각시톱지네 고사리

1. Sori several rows near submarginal site, veinlets plainly immersed D. dickinsii 큰톱지네고사리

\section{ACKNOWLedgements}

This search was supported by grants from "The Survey of new and unrecorded taxa in vascular plants I (NIBR No. 2012-01-040)" founded by the Ministry of Environment of the Korean Government. Thanks to Yang Hoon Cho for guiding at Mudeungsan, and Sun
Yeul Ko for giving photographs.

\section{REFERENCES}

Dong, S.-Y. 2010. A new species of Dryopteris (Dryopteridaceae) from Hainan Island, China. Botanical Studies 51: 537-542.

Flora of China Editorial Committee. 1988-2013. Fl. China in Unpaginated. Science Press \& Missouri Botanical Garden Press, Beijing \& St. Louis.

Fraser-Jenkins, C.R. 1986. A classification of the genus Dryopteris (Pteridophyta: Dryopteridaceae). Bull. Brit. Mus. (Nat. Hist.) Bot. 14:183-218.

Geiger, J.M. and T.A. Ranker. 2005. Molecular Phylogenetics and Historical Biogeography of Hawaiian Dryopteris (Dryopteridaceae). Mol. Phylogenet. Evol. 34:392-407.

Hoshizaki, B.J. and K.A. Wilson. 1999. The Cultivated Species of the Fern Genus Dryopteris in the United States. Amer. Fern J. 89:1-98.

Iwatsuki, K. 1992. Ferns and Fern Allies of Japan. Heibonsha Ltd., Tokyo. pp. 182-201 (in Japan).

Iwatsuki, K. 1995. Dryopteridaceae. Flora of Japan I. In: K. Iwatsuki, T. Yamazaki, D.E. Boufford and H. Ohba (eds.), Kodansha Ltd., Tokyo. pp. 145-167.

Kim, C.H., B.-Y. Sun and Y.B. Kim. 2004. Unrecorded fern species from Korean flora: Ctenitis maximowicziana, Dryopteris lunanensis and D. decipiens var. diplazioides (Dryopteridaceae). Kor. J. Plant Tax. 34:27-35 (in Korean).

Kim, C.H. and B.-Y. Sun. 2007. Dryopteridaceae. In: The flora of vascular plants of Korea. Flora of Korea EdItôrial Committee (eds.), Academy Publishing Co., Seoul. pp. 90-94.

Kurata, S. and T. Nakaike. 1979. Illustrations of Pteridophytes of Japan. Vol. 1. Univ. of Tokyo press, Tokyo (in Japan).

Kurata, S. and T. Nakaike. 1985. Illustrations of Pteridophytes of Japan. Vol. 4. Univ. of Tokyo press, Tokyo (in Japan).

Lee, T.B. 1980. Aspidiaceae. In: Illustrated flora of Korea. Hyang Mun-sa, Seoul (in Korean).

Lee, Y.N. 2006. New flora of Korea. Kyohaksa Publ. Co., Seoul (in Korean).

Li, C.-X. and S.-G. Lu. 2006a. Phylogenetic analysis of Dryopteridaceae based on chloroplast $r b c L$ sequences. Acta Phytotax. Sin. 44:503-515.

Li, C.-X. and S.-G. Lu. 2006b. Phylogenetics of Chinese Dryopteris (Dryopteridaceae) based on the chloroplast rps4trnS sequence data. J. Plant Res. 119:589-598.

Liu, H.M., X.C. Zhang, W. Wang, Y.L. Qiu and Z.D. Chen. 2007. Molecular phylogeny of the fern family Dryopteridaceae inferred from chloroplast $r b c L$ and $a t p B$ Genes. International Journal of Plant Sciences 168:1311-1323.

Lu, S.-G. 1993. A classification synopsis of the genus Dryopteris from Yunnan. Acta Phytotax. Sin. 31:385-391.

Manton, I. 1950. Problems of cytology and evolution in the 
Pteridophyta. Cambridge University Press, Cambridge, UK. pp. 1-316.

Nakaike, T. 1992. New Flora of Japan Pteridophyta Revised and Enlarged. Shibundo Co., Tokyo. pp. 401-433.

Park, M.K. 1975. Illustrated Encyclopedia of Fauna and Flora of Korea. vol. 16. Pteridophyta. Ministry of Education, Seoul. pp. 90-94 (in Korean).

Park, S.H., Y.M. Lee, J.C. Yang, D.G. Cho, G.H. Lee, C.S. Jang, H.J. Lee, H.J. Choi, S.S. Jung and J.H. Choi. 2008. Illustrated Pteridophytes of Korea. Korea National Arboretum, Pocheon. pp. 294-320 (in Korean).

Sessa, E.B., E.A. Zimmer and T.J. Givnish. 2012. Phylogeny, Divergence times, and Historical Biogeography of New world Dryopteris (Dryopteridaceae). Amer. J. Bot. 99:730-750.

Shieh, W.-C., C.E. Devol and C.-M. Kuo. 1994. Dryopteri- daceae. In: Flora of Taiwan. Vol. 1. Pteridophyta, Gymnospermae. EdItôrial Committee of the Flora of Taiwan, Taipei. pp. 316-326.

Stein, D.B., C. Hutton, D.S. Conant, C.H. Haufler and C.R. Werth. 2010. Reconstructing Dryopteris "semicristata" (Dryopteridaceae): Molecular profiles of tetraploids verify their undiscovered diploid ancestor. Amer. J. Bot. 97: 998-1004.

Zhang, L.-B., L. Zhang, S.-Y. Dong, E.B. Sessa, X.-F. Gao and A. Ebihara. 2012. Molecular circumscription and major evolutionary lineages of the fern genus Dryopteris (Dryopteridaceae). BMC Evolutionary Biology 12:180 $(2-15)$.

Submitted: December 18, 2012, Accepted: February 19, 2013 